\title{
Enhancing the Quality of Full-day Kindergarten Education in Korea
}

\author{
Mugyeong Moon \\ Korea Institute of Child Care and Education \\ Korea
}

\begin{abstract}
Increases in the numbers of working mothers, combined with decreases in the levels of support for child-rearing within families in Korea requires the search for alternative forms of support. In order to lessen the burden of childrearing on working mothers, as well as to ensure healthy development and learning environment for children, the Korean government has been striving since the 1990s to expand full-day kindergartens. Despite truly remarkable quantitative expansion and increased governmental financial support, several challenges remain in the provision of quality full-day kindergarten programs. These challenges include an absence of agreed upon educational programs, inadequate classroom environments, a lack of full-day class teachers, amongst other difficulties. In order to understand the current status of full-day kindergartens in Korea, a national survey was conducted. It was found that there are significant differences between public and private kindergartens as well as differences between cities and rural areas. Several policy measures are suggested for quality assurance of full-day kindergartens and related issues are discussed.
\end{abstract}

Key words : full-day kindergarten, full-day program, quality, early childhood policy, Korea

\section{Introduction}

Since the Korean government started to develop policies aimed at implementing a full-day kindergarten program in 1993 in order to meet the needs of dual-income families, Korea has seen a remarkable quantitative growth in full-day kindergartens over the last 15 years. The proportion of

Correspondence concerning this article should be addressed to Mugyeong Moon, Director, Trend Analysis Research Team, Korea Institute of Child Care and Education, Anguk Building 7F, 175-87 Anguk-Dong, Jongno-Gu, Seoul, 110-734, Republic of Korea. Electronic mail may be sent to mgmoon@kicce.re.kr; mgmoon1@gmail.com kindergartens with full-day classes has soared from a mere $29.6 \%$ (2,458 institutions) of all kindergartens in Korea in 2002 to $91 \%$ (7,485 institutions) in 2008, and has reached almost $98 \%$ in 2010. Moreover, 30\% (163,018 children) of the entire population of kindergartener aged children (541,550 children) turned out to attend full-day kindergarten as of April 2010 (Ministry of Education, Science and Technology, 2010).

Such a great increase in full-day kindergarten demonstrates the growing need for a social support system for childrearing. This need can be attributed to the rapidly increasing economic participation of married women as well as decreasing 
assistance from grandparents or relatives in childrearing in Korean society. The rising demand for facilities offering education and care for young children indicates that the government needs to share the responsibility of educating and rearing the children of our nation, which is also important in cultivating the future human resources of Korea (Jung et. al., 2000; $\mathrm{Na}$, 2006).

However, despite the successful quantitative growth of and expanded government funding for fullday kindergarten education over the past decade, there are many challenges which remain unaddressed, including low operating hours, a lack of agreement on adequate education programs, a shortage of full-day kindergarten teachers and personnel fee support policies, and a lack of facilities and equipment for fullday kindergarten operation. In order to tackle these issues, a national survey (Moon \& Kim, 2008) on the current status of full-day kindergartens was undertaken at the end of 2008.

In this paper, the major results of this nationwide survey of full-day kindergarten education are presented and, based on this, possible measures to enhance full-day kindergarten education in Korea are explored. Firstly, the government policies implemented thus far regarding the operation of fullday kindergarten will be introduced.

\section{The Legal Basis and Government Support for the Operation of Full-Day Kindergartens}

\section{The Legal Basis of Full-day Kindergarten Operation}

According to the revised Education Act, kindergartens in Korea started to operate full-day programs for the first time from March 1995, taking into account the characteristics of 16 metropolitan cities and provinces and individual kindergarten's circumstances and educational needs. In 1998, kindergartens were allowed to operate full-day classes, that is, for more than eight hours per day according to the Enforcement Decree of the Elementary and Secondary Education Act and the Early Childhood Education Promotion Act (Law No. 5567/Sep. 17, 1998).

From 2003, the "integrated pre-school education (so called, EduCare)" policy began to be implemented in 19 public kindergartens on a trial basis. In 2008, the number of EduCare kindergartens reached 389 (including 131 public and 258 private kindergartens), up 7.5 fold over five years. Meanwhile, along with the EduCare teachers, the middle- to older-age paid female volunteers ("three-generation harmony teachers") were placed in EduCare kindergartens through cooperative networks among the volunteers (Ministry of Education, Science and Technology, 2008a).

The support systems for the operation of full-day kindergarten was specified for the first time in the Early Childhood Education Act(Clause 3 of Article 12) legislated in January, 2004. Accordingly, financial support has been provided since 2004 for the improvement of full-day kindergarten environments such as classrooms, heating \& cooling systems, sanitation and safety facilities.

The Revised Kindergarten Curriculum 2007, which includes the basic guidelines for the operation of fullday kindergartens, specifies that both "comprehensive care" and "holistic education" should be carried out in an integrated and inclusive manner (Ministry of Education, and Human Resources Development, 2007; Ministry of Education, Science and Technology, 2008b).

\section{Government support for full-day kindergartens}

Funding for improvement of facilities and education environment

The Korean government has provided funding for the improvement of facilities and the educational environments of full-day kindergartens since 2004 for the purpose of expanding the operation of full-day kindergartens and offering better educational 
Table 1

The Legal Basis for the Operation of Full-day Kindergartens

- Pilot operation of full-day kindergartens (by 29 kindergartens): 1993

- Enforcement of guidelines for the operation of full-day kindergartens: 1994

- Establishment of the basis for the operation of full-day kindergartens: 1998

(Enforcement Decree of the Elementary and Secondary Education Act)

- Development \& distribution of full-day kindergarten programs: 2000

- Establishment of the legal ground for the operation of full-day kindergarten: 2004

(Article 27 of the Early Childhood Education Act)

※ Specifying the funding support from central/municipal governments for the operational expenses of full-day kindergartens

- Establishment of appropriate standards for the placement of full-day class teachers: 2005

(Article 33 of the Enforcement Decree of the Early Childhood Education Act)

- Inclusion of the basis for the operation of full-day kindergartens in the Revised Kindergarten Curriculum: 2007

- Support for full-day kindergarten education fees: 2009

Table 2

Funding for facilities $\mathcal{E}$ educational improvement in full-day kindergartens

(Unit : Billion KRW)

\begin{tabular}{cccccc}
\hline Year & 2004 & 2005 & 2006 & 2007 & 2008 \\
\hline Amount & 15 & 50 & 51 & 100 & 200 \\
\hline
\end{tabular}

Note. From Plan for enhancing quality of full-day kindergartens for a customer-oriented early childhood education policy, Ministry of Education, Science and Technology (2008a).

environments for children. Funding has increased by $100 \%$ annually over the last three years from KRW 1.5 billion in 2004 to KRW 20 billion in 2008.

\section{Support for regular teachers at public kindergartens}

The number of full-day class teachers at public kindergartens has decreased from 500 in 2006 to 300 in 2007 and to 150 in 2008. In some cities and provinces, the full-day class teachers have been transitioned to half-day class teachers. As for the private kindergartens, there has been no support for the fullday workforce at all.

Funding for private kindergartens' expenses for teaching materials

The funding for private kindergarten's expenses for teaching materials has steadily increased from KRW 2 billion annually between 2004 and 2006 to KRW 5 billion annually in 2007, and again to an impressive KRW 14.3 billion in 2008.

\section{Support for full-day kindergarten fees}

The support for full-day kindergarten fees has been provided for low-income families since 2009. The total amount of KRW 59,211 million is subsidized for 139,192 children using full-day programs in 2009 (See Table 3).

\section{Literature Review}

Over the course of the last decade, a substantial amount of research has been conducted regarding the operation of full-day kindergartens. The themes of these research activities include the current status of the operation of full-day kindergartens, concepts and 
Table 3

Government subsidies for children enrolled in full-day kindergartens in 2009

(Unit: Number of children, Thousand KRW)

\begin{tabular}{|c|c|c|c|c|c|c|c|c|c|}
\hline \multirow{2}{*}{\multicolumn{2}{|c|}{ Classification }} & \multicolumn{4}{|c|}{ Number of Children supported } & \multicolumn{4}{|c|}{ Amount of Subsidy } \\
\hline & & National & Public & Private & Total & National & Public & Private & Total \\
\hline \multirow{3}{*}{$\begin{array}{l}5 \text { yr. } \\
\text { olds }\end{array}$} & Rural & & 4,435 & 8,302 & 12,737 & & 714,982 & $3,325,985$ & $4,040,967$ \\
\hline & Cities & 2 & 9,767 & 37,324 & 47,093 & 615 & $2,024,215$ & $18,845,244$ & $20,870,074$ \\
\hline & Sub Total & 2 & 14,204 & 45,626 & 59,832 & 615 & $2,739,812$ & $22,171,230$ & $24,911,657$ \\
\hline \multirow{3}{*}{$\begin{array}{l}4 \text { yr. } \\
\text { olds. }\end{array}$} & Rural & & 2,747 & 7,989 & 10,736 & & 439,491 & $3,057,986$ & $3,497,477$ \\
\hline & Cities & 6 & 4,685 & 34,339 & 39,030 & 1,799 & $1,070,836$ & $16,871,910$ & $17,944,545$ \\
\hline & Sub total & 6 & 7,438 & 42,328 & 49,772 & 1,799 & $1,512,127$ & $19,929,897$ & $21,443,823$ \\
\hline \multirow{4}{*}{$\begin{array}{l}3 \text { yr. } \\
\text { olds. }\end{array}$} & Rural & & 1,330 & 5,255 & 6,585 & & 228,727 & $2,014,930$ & $2,243,657$ \\
\hline & Cities & & 1,806 & 21,197 & 23,003 & & 422,772 & $10,189,096$ & $10,611,868$ \\
\hline & Sub total & & 3,136 & 26,452 & 29,588 & & 651,499 & $12,204,026$ & $12,855,525$ \\
\hline & Total & 8 & 24,778 & 114,406 & 139,192 & 2,414 & $4,903,440$ & $54,305,154$ & $59,211,008$ \\
\hline
\end{tabular}

Note. From 2009 Early childhood education fee Support policies, Ministry of Education, Science and Technology (2010).

programs of full-day kindergartens, perceptions of full-day kindergarten teachers, and so on. Based on the results of previous research, the concept of fullday programs can be defined as a comprehensive program that covers all developmental stages of children as well as integrated and expanded educational activities aimed at the well-rounded development of children, which involve education and care linked to half-day programs (Hong et al., 2007; Jung et al., 2000; Lee et al., 2005; Seo et al., 2003).

The difficulties in the operation of full-day kindergartens include the heavy workload and the work hours of teachers, the lack of equipment/ facilities and lack of appropriate educational programs (Bae et al, 2005; Kim, 2003). In particular, as for the full-day programs, there is a need to develop a comprehensive program that is suited to children of all developmental stages, whilst taking into consideration the fact that most of the full-day classes are composed of a group of children of different ages. In addition, the national curriculum for the afternoon sessions of full-day kindergartens should be revised in a way that meets the demands of parents, who want their children to engage in extracurricular activities in such areas as art, music, letters, math, etc. (Kim, 2005; Lee et al, 2002; Lee \& Shin, 2005).

Another area for improvement is to incorporate the activities that children only rarely experience (e.g. shopping, cooking, bonding between siblings, etc.) into the full-day programs and to strengthen the link between morning and afternoon sessions. According to the research conducted by Park (2007), educational programs suited for a mixed-age group should be developed by referring to the developmental levels I \& II in the national kindergarten curriculum. This is especially important in that it is difficult to implement a curriculum suited for every child in cases where the gap in children's ages is more than one year within 
one class.

Meanwhile, in the research on the extracurricular activities conducted during the afternoon session, the fact that the activities are taught by teachers without licenses is identified as the biggest problem. This is followed by the pressure imposed on children and the problems related to preparation and implementation of regular classes (Lee et al, 2002). Most of the research also suggests that there should be at least two teachers for one full-day class (two regular teachers, or one regular teacher and one assistant teacher) (Ahn, 2009).

As for the issue of equipment/facilities, the lack of the places where children can take a nap has also been identified as a major problem as a lack of sleep or fatigue could interfere with children's learning and physical development (Park et al., 1998; Shin, 2008).

\section{Status of the Operation of Full-day Kindergartens}

A nationwide online survey of kindergartens that offer full-day classes was conducted and a total of 4,152 kindergartens participated (public $63.1 \%$, private $36.9 \%$ ). In the survey, 57 questions were given under seven categories (related to the number of classes and enrolled children, operation system, teachers, costs and government support, programs, family engagement, quality assessment and the kindergartens' needs). The main results of the survey are as follows:

\section{Basic information on full-day kindergarten}

Statistics on kindergartens, classes and enrolled children

As noted previously, the total number of kindergartens that offer full-day sessions in Korea stands at 7,485 as of 2008, with public kindergartens showing a slightly higher rate $(53.5 \%)$ than private kindergartens (46.7\%). The number of full-day classes were 9,458 in total (national/public kindergartens: 4,574 classes, private kindergartens: 4,884 classes), and the number of children who attend full-day kindergarten stood at $30 \%$ of a total of 541,550 kindergarteners, up by $18 \%$ (or 17.5 children per class) compared to 2007 (Ministry of Education, Science and Technology, 2008a).

According to a national survey, most of the kindergartens offer only one full-day class (public: $87 \%$, private: $75.4 \%$ ). As for the ratio of kindergartens offering two to three full-day classes, private kindergartens showed higher percentages (2 classes: 17.3\%, 3 classes: $7.3 \%$ ) than the public institutions (2 classes: $10.9 \%, 3$ classes: $2.1 \%)$.

In terms of length of stay, the average number of students staying at full-day classes for less than 8 hours and less than 8-10 stood at 16 per institution, the highest rate, and the number of those who stay for less than 10-12 hours stands at 11, ranked second highest, and the number of those who stay for 12 hours or over is estimated at 2. By age cohort, it has been found that the older the age of the children, the more they are likely to attend full-day classes, with the average number of children age 3 in full-day classes per institution being 5 , age 4 being 8 , and age 5 being 11 , out of a total average of 21 full-day class pupils per institution. Meanwhile, the average number of children on waiting lists to enter full-day classes per institution stands at five, with the public kindergartens having higher numbers of children on such waiting lists on average than private institutions. The average number of full-day class children whose mothers are working is estimated at 14 per institution, in which the private kindergartens post larger numbers than the public institutions.

\section{Statistics on teachers}

The nationwide statistics on full-day class teachers are as follows:

According to this survey, as for the full-day class teachers, the number of non-regular teachers is three times higher than regular teachers. In addition, the differences by regions are quite high, ranging from two to eight fold. The average number of class teachers per kindergarten stands at three, and the 
Table 4

Statistics on full-day class teachers in kindergartens (2008)

\begin{tabular}{lcccccc}
\hline & $\begin{array}{c}\text { Teachers } \\
\text { dedicated to } \\
\text { full-day classes }\end{array}$ & $\begin{array}{c}\text { Teachers undertaking } \\
\text { both morning \& } \\
\text { afternoon classes }\end{array}$ & Instructors & $\begin{array}{c}\text { Instructors } \\
\text { without license }\end{array}$ & $\begin{array}{c}\text { Assistant } \\
\text { workforce }\end{array}$ & Total \\
\hline No. of persons & 792 & 2604 & 2155 & 127 & 5801 & 11,479 \\
\hline Percentage (\%) & 6.9 & 22.7 & 18.8 & 1.1 & 50.5 & 100.0 \\
\hline
\end{tabular}

Note. From Plan for enhancing quality of full-day kindergartens for a customer-oriented early childhood education policy, Ministry of Education, Science and Technology (2008a).

average number of full-day class teachers, regular or non-regular, is one person. Some kindergartens have nutritionists and cooks for the full-day class children, but most of the kindergartens were found not to have these personnel in place.

\section{Overall status of the operation of full-day kindergartens}

\section{Operation hours}

Most of the kindergartens are operating their fullday program for less than eight hours or less than eight to ten hours per day. As for the closing time of full-day classes, $31.5 \%$ of national/public kindergartens run classes until 4:00 or 5:00 pm, while $41.9 \%$ of private kindergartens continue classes until 7:00 or 8:00 pm, meaning that the private institutions run full-day programs three hours longer than national/public institutions. Meanwhile, in large cities, the rate of kindergartens which run full-day sessions until after $6: 00 \mathrm{pm}$ stood at $81.3 \%, 13.9 \%$ of which continue classes until after 8:00 pm. This translates into the fact that the kindergartens in large cities operate full-day program for longer hours than those in small and medium-sized cities or towns.

The proportion of kindergartens providing Saturday classes every other week is hovering at around 51.6\%, while those that offer Saturday classes every week stand at $25.6 \%$ and those without Saturday classes stand at $22.8 \%$. It has been also found that $71.5 \%$ of the national/public kindergartens provide Saturday classes biweekly, while $56.2 \%$ of private kindergartens provide them every week. In large cities, the proportion of the kindergartens offering Saturday classes every week is higher, while in small and medium sized cities or towns the rate of those providing Saturday classes biweekly is higher. The vacation period of full-day kindergartens lasts for 33 days on average. The vacation days of national/ public kindergartens are more than four times as many as those of the private kindergartens (46 days vs. 11 days).

\section{Organization and composition of full-day classes}

As for the way of organizing full-day classes, $76.1 \%$ of kindergartens gather children for the afternoon class after completing morning class rather than having children stay throughout the day in the same classroom. In terms of the ages of full-day class pupils, $79.9 \%$ of the classes are composed of children of mixed ages. As for the rates of single-aged classes, the national/public kindergartens have almost three times the number of single-aged classes than the private kindergartens (17.9\% vs. $6.5 \%)$.

\section{Programs}

Of all the kindergartens surveyed, 96.5\% develop separate education plans for full-day classes, and in most cases (39.4\% of kindergartens), the full-day class teacher alone undertakes this work. As for the afternoon session programs, a majority $(74.7 \%)$ of kindergartens offer diverse programs that are different from the morning-session programs, though 
they are linked with each other, and the rate of those that are focusing on childcare activities during the afternoon session amounts to a mere $2.9 \%$.

In terms of the reasons for implementing extracurricular activity (so called, special) programs in the full-day classes, a majority of kindergartens $(47.9 \%)$ responded that it was because they needed to promote program diversity. On average, each kindergarten offers two extracurricular activity programs (one for free and another fee paying) for full-day classes. Each kindergarten has two extracurricular activity teachers on average, and most of them do not have teacher's licenses. The average tuition for extracurricular activity programs ranges from KRW 16,616 to KRW 25,890. It should be noted, however, that these fees are quite low compared to the real fees that are actually charged by kindergartens.

The rate of the full-day kindergartens that do not provide meals during vacation stands at $73.3 \%$, and among these, $75.6 \%$ are the national/public kindergartens. Moreover, $57.8 \%$ of all kindergartens surveyed do not provide transportation for full-day class children.

\section{Placement, work hours and labor costs of teachers}

A majority of kindergartens (67.9\%) have teachers dedicated to the afternoon session of the full-day program, but private kindergartens are more likely to have morning-session teachers who also undertake the afternoon sessions, alternately. The gap in average monthly wages of full-day teachers between the national/public and private kindergartens is KRW 1,102,306 (national/public: KRW 2,273,596, private: KRW 1,171,290). The average wages of instructors at national/public institutions are twice as much as those of the instructors at private institutions.

\section{Educational expenses and government support}

The average additional charges for full-day classes per child of private kindergartens are KRW $75,000 \sim 78,000$ higher than those of public kindergartens. Meanwhile, up to $89.6 \%$ of the kindergartens surveyed are being financially supported by the government in terms of full-day class operation. Of this support, $98 \%$ comes from the regional offices of education. The area where the financial support is mostly spent turned out to be the labor costs for teachers, which is followed by the improvement of educational environments and the costs of textbooks and teaching tools.

\section{Needs of parents and kindergartens}

The parents' needs regarding full-day classes, as perceived by the kindergartens, include the need for diverse education programs (56.0\%), operation during vacation $(30.6 \%)$, provision of meals/snacks and nutritious food (24.2\%), instructions on safety (18.2\%) and extension of class hours (15.3\%). Among such requests, the public/national kindergartens show higher rates than private kindergartens in the following areas; the need for more diverse educational programs $(61.8 \%)$ and operation during vacation (34.4\%). On the other hand, the private institutions show higher rates than public/national kindergartens in the provision of meals/snacks and nutritious food (28.3\%), reduction in education expenses $(18.1 \%)$ and operation on Saturday (6.8\%). The difference by region is not significant, but in small towns the demand for operation during vacation (40.4\%) and extension of class hours $(18.4 \%)$ was higher than in other regions. Meanwhile, the kindergartens point out that securing full-day class teachers is the most urgent issue that should be addressed in order to expand the operation of full-day classes.

\section{Full-day Kindergarten Enhancement Measures}

Based on such results from the national survey, several policy measures to enhance the operation of full-day kindergarten programs are suggested below. 


\section{Expanding opportunities for participating in full-day} kindergartens

\section{A 'No child on the waiting list' policy}

It is suggested to guarantee access to full-day classes for all children who want to do so by the end of 2010. Through that the survey (Moon \& Kim, 2008), an average of five children were found to be on waiting lists to join the full-day classes per kindergarten. Therefore, the city or provincial superintendents need to ensure the opportunities for children to participate in the full-day classes, taking into account the circumstances of each region. Initially, the policy guaranteeing places in full-day classes within 90 days of application can be implemented in several regions on a test basis, and later can be expanded throughout the nation under the oversight of regional offices of education.

Giving priority for using full-day kindergarten to children from disadvantaged families

Several studies have shown the positive effects of full-day kindergartens on disadvantaged children (Brooks, 2008; Schroeder, 2007). A priority should be given in terms of access to full-day classes to the children from the Priority Region of Educational Welfare, the areas highly populated with underprivileged dual-income families, single parentfamilies, grandparent-grandchildren families, multicultural families and other disadvantaged families. In order to establish the legal framework for this, the government should incorporate the relevant provision in the Early Childhood Education Act (Clause 2 of Article 10: Kindergarten Regulations). Furthermore, the eligibility for those who can benefit from government support in terms of fullday kindergarten needs to be clarified, so that those who really need help are not excluded from this support.

12 hours per day $\mathcal{E} 300$ days per year operation

Redefine the previous concept of full-day kindergarten where the operation hours are defined as " 8 hours or over per day." The research evidence indicates that "operation during vacation" is the second most important demand by parents regarding full-day kindergarten programs. In addition, a large proportion of private kindergartens and the kindergartens in urban areas are already operating full-day classes for 10-12 hours or over a day. However, it should be noted that this suggestion regarding the daily class hours or annual operation days is not intended to be applied invariably to all full-day classes.

\section{Enhancing quality of full-day kindergarten programs}

Provision of support customized to public and private full-day kindergartens

According to the national survey, the most pressing issues for public kindergartens are to secure full-day class facilities suited for each developmental stage of children as well as the support for these facilities, to increase the full-day classes for those who are on the waiting list, to secure classrooms dedicated to full-day program, and to hire more regular, full-day class teachers. As for the private kindergartens, the major areas of improvement include full-day programs focused on special activities, securing classrooms dedicated to full-day programs, hiring more regular full-day class teachers, and enhancing the engagement of parents. As such, the support for full-day teachers of public kindergartens should be different from the support for private kindergartens. For the former, the support should be focused on securing full-day teachers, while for the latter, the financial support for the labor costs of full-day teachers should be provided. Full-day teacher training programs should also be different. A large proportion (63.9\%) of national/ public kindergartens see the need for training for "various programs," while many of the private kindergartens require the training aimed at both "various programs (38.9\%)" and "guidelines for teaching a mixed-age class (37.9\%)." 
Currently, the government is providing the financial support for the operation of full-day kindergartens. However, $16.2 \%$ of private kindergartens have not received any support from the government at all, which is a high proportion compared to $7.0 \%$ of public kindergartens. Moreover, the spending on teachers' labor costs by the national/public kindergartens is six times higher than that of the private kindergartens. Therefore, the government needs to increase its support for private kindergartens, enhancing fairness in its support.

Diversification of operation models of full-day kindergarten by region

The current operation model of full-day kindergarten can be categorized into both the "urban type" and "rural type," so as to diversify the manner of class organization, operation hours, teacher placement and programs for full-day kindergartens. As for the rural type, it would be more efficient to operate full-day classes at a certain designated kindergarten with good accessibility not only during the regular semester but also during the vacation period. In addition, circulating transportation should be provided, and the cost for using this transportation should become affordable. Government support is especially needed for the small and medium sized private full-day kindergartens (with 2-3 or less classes) in urban areas which have scarce human and financial resources.

Development $\mathcal{E}$ distribution of full-day programs and introduction of visiting-teacher system

Developments need to be made in providing various full-day programs suited for each kindergarten by type (public or private), region, ways of class organization (adding afternoon sessions or separate full-day sessions) and age composition of a class (mixed age groups or a single age group). Most of all, alternative programs for extracurricular (so called, "special") activities should be developed. According to the national survey, almost $20 \%$ of private kindergartens offer full-day programs focused on special activities and childcare, and, furthermore, the users of the extracurricular activities should bear the cost of these activities. As such, there has been a great deal of concern over proper education programs for full-day classes, especially for the afternoon sessions. Apart from this, in terms of the parents' needs as perceived by kindergartens, "provision of diverse programs" was as high as $56.0 \%$ (national/public $61.8 \%$; private $45.9 \%$ ).

The strategies kindergartens could employ to meet such needs of parents are as follows:

i) Develop specialized music, art and physical education programs as in Germany and France and implement such programs at kindergartens or at the government-supported centers (Jung et al., 2000).

ii) Designate extracurricular activities for each weekday and let children move to the respective classroom for each activity (e.g., Samsung elementary school attached kindergarten in Jeju city).

iii) Enhance parent education on the purposes and functions of the extracurricular activities.

Thus far, the central and municipal governments have developed and distributed full-day programs. However, these programs are not easy to implement or utilize on a widespread basis as they are not comprehensive enough to be applied to many full-day classes, as opposed to just a collection of simple activities as is currently the case. Alternative measures to address this issue include utilizing the "visiting extracurricular-activity teachers" who belong to the regional offices of education or enabling kindergartens to utilize the instructors of the Arts Council of Korea. Even though some kindergartens provide diverse educational activities and experiences for children by tapping into the specialties of individual kindergarten teachers, many parents still tend to put more trust in external professional instructors. In this regard, the government should support kindergartens to hire "visiting extracurricular- 
activity teachers" belonging to the regional offices of education or to build cooperative networks with the Arts Council of Korea so that kindergartens can utilize the instructors of this organization. The kindergartens should be granted autonomy in operating these systems, but at the same time the government should provide relevant guidelines and regulations and have the kindergartens keep records of the operation process.

\section{Placement of full-day class teachers}

Specify the conditions of regional offices of education for full-day class teacher placement as follows, as a means to secure more full-day class teachers: The full-day class teachers will be placed with special priority at the kindergartens which, i) utilize their own teaching human resources, ii) provide childcare services within elementary schools, or iii) guarantee extended class hours through cooperation with neighboring childcare facilities. In addition, the regional offices of education should consider easing the regulations on teacher employment by private kindergartens to help the private kindergartens secure more full-day class teachers and improve the quality of full-day programs, and come up with measures to recognize the work experiences of full-day class teachers. The "education support tour system" should also be facilitated, in which the teachers belonging to the regional offices of education may be hired by the individual kindergartens without the teachers for full-day classes.

\section{Establishment of on- E off-line networks for full-day class} teachers

The establishment of nationwide or regional onand off-line networks for full-day class teachers needs to be established so that they can share their feelings and difficulties as well as useful information to overcome the challenges they face. At the individual kindergarten level, the cooperation system and networking system between the morning class teachers and afternoon/full-day class teachers should be established, and it should include communication, information sharing, keeping a daily record of class operations together, joint program development, etc. The government needs to provide technical and financial support for such networks for at least two to three years so that these networks can be utilized as the communication channels of full-day class teachers as well as a means to improve their expertise.

\section{Enhancement of parental involvement}

It is suggested that incorporating the expectations and needs of parents be mandatory when it comes to the full-day programs. Given that the full-day class children spend more time in kindergartens than at home, it is essential to identify the needs of their parents and collect information on their family life. However, according to the survey, the full-day class teachers hardly make any effort to acquire information on their children's developmental status or family life from their parents. Moreover, out of the six performance items for self-evaluation, "engagement of parents and families" was rated the lowest. Moreover, in the responses to the question, "what is the most urgent issue that needs to be resolved in order to promote full-day classes," the engagement of parents and families ranked lowest as well, demonstrating the lack of interest and effort on the part of kindergartens in engaging parents and families in full-day programs.

In order to address this issue, a certain number of parents of the full-day class children should be included in a parents' committee, and various ways (texting, phone-calls, etc.) should be developed and utilized to facilitate communication between teachers and working parents. In addition, an orientation and satisfaction survey should be carried out for the parents of full-day class children, and, most of all, teacher-parent meetings should be held on a regular basis with the participation of the parents of full-day class children.

Other policy efforts that are required include: strengthening the levels of professional support for 
full-day class teachers, developing measures to temporarily (or regularly) provide extended hours of childcare (for 12 hours or over) through the full-day classes to meet the various needs of families (e.g. parents working overtime or working in three shifts, parents with illnesses or disabilities, etc.), setting the standards of support for full-day class children, conducting preliminary studies for setting the standards for the designation of full-day kindergartens in rural areas, and raising the awareness of the public and parents on the effectiveness and variety of full-day kindergarten programs.

What should be considered foremost in implementing these policy measures is the perspectives and interest of young children, who spend long hours in kindergartens, and these children's rights to receive quality education and care services. The government also needs to improve the quality for parents in a more tangible way. Lastly, the full-day kindergarten should be a comfortable and welcoming place of living, teaching and learning not only for children but also for their teachers.

\section{References}

Ahn, J. (2009). 전문인력과의 협력에 기반을 둔 유치원 종일반 프로그램의 바람직한 운영방안 [Measures for implementation of full-day kindergarten program based on cooperation with various professional workforces]. Early Childhood Education and Care Forum, 1, 20-33.

Bae, J. Lee, B., \& Tahg, O. (2005). 공사립 유치원 종일반 운영의 실제에 대한 문화기술적 탐구: 교사의 경험과 인식을 중심으로 [An ethnographic approach to the practices of full-day programs in public and private kindergarten: Focusing on teachers' experiences and perspectives]. Early Childhood Educational Research, 25(1), 237-258.

Brooks, L. M. (2008). Full-day kindergarten: A step towards breaking the cycle of poverty in indiana.
Journal of Law \& Education, 37(3), 437-442.

Hong, Y., Kim, G., Kang, K., \& Kim, S. (2007). 유치원 종일제 프로그램의 바람직한 운영방안 [Developing ways for quality full-day kindergarten programs]. Early Childhood Educational Research, 27(5), 335-355. Jung, M., Hong, Y., Eum, J., \& Lee, S. (2000). 유치원 종일제 프로그램의 운영실태에 대한 연구 [A study on full-day kindergarten programs]. Early Childhood Educational Research, 20(1),

Kim, G. (2005). 유치원의 특기적성 교육활동에 대한 학부모와 교사의 인식 및 만족도 비교 연구 [Comparative analysis on perspectives and satisfaction of parents and teachers on extracurricular activities in kindergartens]. Unpublished Masters' thesis, Graduate School of Education, Dongguk University, Seoul, Korea.

$\mathrm{Kim}, \mathrm{H}$. (2003). 공립 유치원 종일제 운영 실태 및 개선 방향 [Current status and directions for improving full-day programs in public kindergartens]. Unpublished Masters' thesis, Graduate School of Education, Ewha Women's University, Seoul, Korea.

Kim, K., \& Kim, J. (2007). 유치원과 어린이집 종일제 프로그램 운영 실태와 교사 인식 비교 연구 [Comparison of teacher perceptions and operation of full-day programs in kindergartens and childcare centers]. Early Childhood Educational Research, 10, 55-75

Kim, S. (2005). 한국사회 저출산의 원인과 대응 전략 [Causes and coping strategies for the low birth phenomenon in Korea] (Research report). Seoul, Korea: Korea Institute of Health and Social Affairs.

Kim, Y., \& Seo, Y. (2006). 보육시설과 유치원 특별활동의 현안과 쟁점: 발달적합성과 사회·문화 적합성을 중심으로 [Current issues and challenges of extracurricular activities in childcare centers and kindergartens: Focusing on developmental and socio-cultural appropriateness]. Journal of Future Early Childhood Education, 13(2), 115-136.

Lee, K., Jang. Y., Jung, M., \& Hong, Y. (2002). 유치원에서의 특별활동 실시 현황 및 교사의 인식 
[The current status of and teachers' perception on extracurricular activities in kindergarten]. Journal of Korean Society for Child Study, 23(4), 137-152.

Lee, M. (2005). 유치원의 종일반 운영 실태에 관한 연구 [The operation of full-day kindergartens]. Journal of Open Early Childhood Education Research, 9(3), 333-349.

Lee, Y., \& Shin, E. (2005). 유치원 독립 종일제 프로그램과 오후 별도 종일제 프로그램의 운영 실제 비교연구 [A comparative study on operation of independent and reorganized fullday classes]. Journal of the Korean Society for Child Care, 8, 1-31.

Ministry of Education and Human Resources Development. (2007). National Kindergarten Curriculum (Document No. 2007-153). Seoul, Korea: Author.

Ministry of Education, Science and Technology. (2008a). 수요자 중심 유아교육 정책 개편을 위한 유치원 종일반 운영 내실화 추진계획 [Plan for enhancing quality of full-day kindergartens for a user-oriented early childhood education policy] (Internal document). Seoul, Korea: Author.

Ministry of Education, Science and Technology. (2008b). 유치원 지도서 13: 종일반 [Guidebook for kindergarten No. 13: Full-day kindergarten]. Seoul, Korea: Author.

Ministry of Education, Science and Technology. (2010). 2009 년도 유아학비 지원 정책 [2009 Early childhood education fee support policies] (Internal document). Seoul, Korea: Author.

Moon, M., \& Kim, M. (2008). 유치원 종일반 운영실태 조사 [National survey of full-day kindergarten] (Research Rep. 2008-11). Seoul, Korea: Korea Institute of Child Care and Education.

$\mathrm{Na}$, J. (2006). 유치원 종일제 운영 확대 정책 [Policies for expanding full-day kindergarten programs]. Early Childhood Education and Care Forum, 1, 20-33.

Park, H., Ahn, L., \& Ha, Y. (1998). 종일제와 반일제 유치원 프로그램의 유아스트레스 행동 [Young children's stress behaviors in half-day and full- day kindergarten programs]. Early Childhood Educational Research, 18(2).

Park, J. (2007). 공.사립 유치원 에듀케어 프로그램의 혼합연령학급 운영 실제 및 교육적 효과에 대한 교사의 인식 [Teacher perspectives on operation of mixed-age EduCare programs and their educational effects]. The Journal of Korean Society for Early Childhood Teacher Education, 11(2), 161-182

Schroeder, J. (2007). Full-day kindergarten offsets negative effects of poverty on state tests. European Early Childhood Education Research Journal, 15(3), 427-439.

Seo, W. \& Kim, K. (2003). 종일제 유치원의 실태분석을 통한 영유아보육사업의 향후 대응 방안 모색에 관한 연구 [Developing a plan for childcare based on an analysis of the current status of full-day kindergartens]. Research on Childcare, 34, 285-313

Shin, H. (2008). 유치원 오후재편성 종일반 유아들의 스트레스에 관한 문화기술적 연구 [Qualitative study on stress of young children in full-day kindergarten programs]. Unpublished Masters' thesis, Sungshin Women's University, Seoul, Korea.

Yoo, J. \& Hong, Y. (2006). 만 4,5세 혼합연령 종일반 유아들의 관계 형성에서 나타나는 특성에 관한 문화기술적 연구 [An ethnographic study on peer relationships of 4- and 5-year-olds in mixed-age full-day class]. Early Childhood Educational Research, 28(3), 177-200. 